\title{
Laporan Keuangan Wajib Pajak UMKM Berbasis SAK EMKM Sebagai Dasar Pelaporan SPT Tahunan
}

\author{
Nurul Aisyah Rachmawati ${ }^{1}$, Rizka Ramayanti ${ }^{2}$, Muyassaroh $^{3}$, Sri Opti ${ }^{4}$ \\ 1,2,3,4Program Studi Akuntansi, Fakultas Ekonomi dan Bisnis, Universitas Trilogi \\ email: ${ }^{1}$ nurulaisyah@universitas-trilogi.ac.id, 2rizka.ramayanti@trilogi.ac.id, \\ ${ }^{3}$ muyassaroh@trilogi.ac.id, ${ }^{4}$ sriopti@trilogi.ac.id
}

\begin{abstract}
Abstrak
Sebagai wujud pemenuhan Tri Dharma Perguruan Tinggi, Program Studi S1 Akuntansi Universitas Trilogi tidak hanya berfokus pada bidang pengajaran dan penelitian saja, melainkan juga pada bidang pengabdian kepada masyarakat. Bekerjasama dengan Kantor Wilayah DJP Jakarta Selatan 1, Program Studi S1 Akuntansi Universitas Trilogi melakukan pelatihan penyusunan laporan keuangan berbasis SAK EMKM untuk Wajib Pajak UMKM di dalam nauangan KPP Pancoran Jakarta sebagai dasar pelaporan SPT Tahunannya. Pengetahuan Wajib Pajak UMKM yang berada dalam naungan di dalam nauangan KPP Pratama Pancoran Jakarta Selatan terkait pelaporan keuangan dan pajak masih sangat terbatas. Hal inilah yang mendasari Tim Pengabdian untuk melakukan pelatihan penyusunan laporan akuntansi dan pajak. Pelatihan ini terdiri tiga sesi: 1) pemberian materi tentang penyusunan laporan akuntansi; 2) pemberian materi tentang penyusunan laporan pajak; serta 3) diskusi dan tanya jawab dengan peserta pelatihan. Oleh karena antusiasme peserta sangat tinggi, kegiatan pelatihan ini dilanjutkan dengan sesi pendampingan penyusunan laporan keuangan dan pajak yang diselenggarakan di Universitas Trilogi. Dengan demikian, para peserta mendapatkan pemahaman dan pengetahuan yang lebih baik tentang penyusunan laporan keuangan berbasis SAK EMKM.
\end{abstract}

Kata Kunci: UMKM, laporan keuangan, laporan pajak

\section{Abstract}

As a form of fulfilling the Tri Dharma Perguruan Tinggi, Department of Accounting Universitas Trilogi does not only focus on teaching and research, but also on community service. In collaboration with Kantor Wilayah DJP Jakarta Selatan 1, Department of Accounting Universitas Trilogi conducted training in preparing financial reports based on SAK EMKM for SME Taxpayers in the KPP Pancoran Jakarta as the basis for reporting their Annual Tax Return. The knowledge of SME Taxpayers in the KPP Pancoran Jakarta about financial and tax reporting is still very limited. This is what underlies the Community Service Team to conduct training activities in preparing financial and tax reports. The training consisted of three sessions: 1) giving material on preparing financial reports; 2) providing material about preparing tax reports; and 3) discussion and QEA with the training participants. Because of the enthusiasm of the participants was very high, the training activities were followed by a mentoring session on the preparation of financial and tax reports held at 


\section{JURNAL ABDIMAS BSI}

Jurnal Pengabdian Kepada Masyarakat

Universitas Trilogi. Thus, participants get a better understanding and knowledge about preparing financial reports based on SAK EMKM.

Keywords: SME, financial reporting, tax reporting

\section{Pendahuluan}

Usaha Mikro, Kecil, dan Menengah (UMKM) berpotensi untuk menggerakkan roda kegiatan ekonomi Indonesia. Berdasarkan data terakhir yang dipublikasikan oleh Kementerian Koperasi dan UKM, perkembangan jumlah UMKM di Indonesia sebesar 2,00\% untuk Usaha Mikro, 3,44\% untuk Usaha Kecil, dan 3,54\% untuk Usaha Menengah. Selaras dengan hal tersebut, keberadaan UMKM ini dapat meningkatkan Produk Domestik Bruto (PDB) Indonesia yang cukup signifikan. Perkembangan PDB untuk Usaha Mikro sebesar 9,85\%, untuk Usaha Kecil sebesar 9,14\%, dan untuk Usaha Menengah sebesar 9,39\% (Kementerian Koperasi dan UKM, 2018).

Namun demikian, adanya tren positif tersebut tidak selaras dengan besarnya penerimaan negara yang berasal dari pajak di sektor UMKM. Menurut Rachmawati dan Ramayanti (2016), kesenjangan ini mengindikasikan rendahnya tingkat kepatuhan Wajib Pajak UMKM dalam memenuhi kewajiban perpajakannya. Rendahnya tingkat kepatuhan tersebut juga dapat disebabkan oleh rendahnya pengetahuan Wajib Pajak (Maulinda dan Lasmana, 2015; Darmayanti dan Rahayu, 2017; Indrawan dan Binekas, 2018; Raflis et al., 2019), termasuk pengetahuan tentang penyusunan laporan keuangan dan pajak.

Wajib Pajak UMKM umumnya memiliki sumber daya manusia yang terbatas, sehingga seringkali mengalami kesulitan dalam memahami proses penyusunan laporan keuangan dan pajak karena terlalu fokus dalam menjalankan proses bisnisnya. Oleh sebab itu, Dewan Standar Akuntansi Keuangan (DSAK) dan Direktorat Jenderal Pajak (DJP) selaku regulator memberikan perlakuan khusus dalam penyusunan laporan keuangan dan pajak untuk para pelaku UMKM.

Dalam konteks akuntansi, DSAK telah mengesahkan Standar Akuntansi Keuangan Entitas Mikro, Kecil, dan Menengah (SAK EMKM) pada tanggal 1 Januari 2018. Jika dibandingkan dengan SAK yang lain (SAK Entitas Tanpa Akuntabilitas Publik dan SAK Umum yang berbasis IFRS), SAK EMKM relatif lebih sederhana. Dengan demikian, diharapkan pelaku UMKM dapat lebih mudah memahami dan menerapkan SAK tersebut dalam penyusunan laporan keuangannya (Onasis et al, 2017; Raflis et al., 2019).

Dalam konteks perpajakan, regulator juga telah memberikan insentif pajak untuk Wajib Pajak UMKM. Insentif pajak yang dimaksud berupa kemudahan dalam pemenuhan kewajiban perpajakannya, baik penghitungan, penyetoran, maupun pelaporan pajak (Rachmawati dan Ramayanti, 2016; Firmansyah et al., 2019). Berdasarkan Peraturan Pemerintah Nomor 23 Tahun 2018 tentang Pajak Penghasilan atas Penghasilan dari Usaha yang Diterima atau Diperoleh Wajib Pajak yang Memiliki 


\section{JURNAL ABDIMAS BSI}

Jurnal Pengabdian Kepada Masyarakat

Peredaran Bruto Tertentu, Wajib Pajak UMKM dikenai Pajak Penghasilan yang bersifat final sebesar 0,5\% dari omzet untuk jangka waktu tertentu. Dengan tarif yang relatif kecil, pengenaan pajak didasarkan pada omzet, dan pajak yang bersifat final, Wajib Pajak UMKM akan lebih mudah dalam melakukan penghitungan, penyetoran, dan pelaporan pajaknya di akhir tahun.

Kesulitan dalam penyusunan laporan keuangan dan pajak merupakan hambatan yang dihadapi oleh Wajib Pajak UMKM di dalam naungan Kantor Pelayanan Pajak (KPP) Pratama Pancoran Jakarta Selatan. Bekerjasama dengan Kantor Wilayah DJP Jakarta Selatan 1, tim pengabdian melakukan kegiatan pelatihan penyusunan laporan keuangan untuk Wajib Pajak UMKM berbasis SAK EMKM sebagai dasar pelaporan Surat Pemberitahuan (SPT) Tahunan. Tujuan diselenggarakannya kegiatan pengabdian kepada masyarakat ini adalah untuk memberikan pemahaman dan pengetahuan kepada Wajib Pajak UMKM tentang penyusunan laporan keuangan berbasis SAK EMKM. Dengan adanya pemahaman tesebut, diharapkan Wajib Pajak UMKM dapat melaporkan SPT Tahunannya dengan benar, lengkap, jelas, dan tepat waktu. Dengan adanya kegiatan ini, tidak hanya Wajib Pajak UMKM saja yang mendapatkan pengetahuan baru terkait penerapan SAK EMKM, tetapi juga fiskus dari KPP Pratama Pancoran Jakarta Selatan dan Kantor Wilayah DJP Jakarta Selatan 1 yang hadir dalam acara tersebut. Hal ini terjadi mengingat pemberlakuan SAK EMKM yang relatif baru.

\section{Metode}

Kegiatan pengabdian kepada masyarakat ini dilakukan dalam bentuk pelatihan penyusunan laporan keuangan berbasis SAK EMKM yang dijadikan dasar untuk pelaporan SPT Tahunan. Oleh karena kegiatan ini diselenggarakan bekerjasama dengan Kantor Wilayah DJP Jakarta Selatan 1, peserta pelatihan terdiri dari 50 Wajib Pajak UMKM yang berada dalam naungan KPP Pratama Pancoran Jakarta Selatan yang satu kawasan dengan Universitas Trilogi. Selain itu, kegiatan ini juga dihadiri perwakilan dari KPP Pratama Pancoran Jakarta Selatan dan Kantor Wilayah DJP Jakarta Selatan 1. Pelatihan sehari ini dilakukan di Aula Mal Pelayanan Publik, Jakarta Selatan. Pelatihan ini terdiri tiga sesi, yaitu:

1) Pemberian materi tentang penyusunan laporan akuntansi berbasis SAK EMKM;

2) Pemberian materi tentang penyusunan laporan pajak berdasarkan Peraturan Pemerintah Nomor 23 Tahun 2018; serta

3) Diskusi dengan peserta pelatihan.

Kegiatan pengabdian kepada masyarakat ini juga melibatkan 8 mahasiswa Program Studi S1 Akuntansi Universitas Trilogi yang juga bertugas sebagai Relawan Pajak untuk mendampingi para peserta di sesi diskusi dan tanya jawab. Oleh karena antusiasme peserta sangat tinggi, kegiatan pelatihan ini dilanjutkan dengan sesi pendampingan penyusunan laporan keuangan dan pajak yang diselenggarakan di Universitas Trilogi. Sesi pendampingan hanya diperuntukkan bagi Wajib Pajak UMKM yang memiliki kasus khusus dan merasa perlu pendampingan, seperti Wajib 


\section{JURNAL ABDIMAS BSI}

Jurnal Pengabdian Kepada Masyarakat

Pajak yang tidak memiliki latar belakang akuntansi, Wajib Pajak yang usahanya baru berdiri, dan sebagainya.

\section{Hasil dan Pembahasan}

Pengabdian kepada masyarakat sejatinya ditujukan untuk menyebarluaskan ilmu pengetahuan, teknologi, dan seni kepada masyarakat, seperti halnya kegiatan pelatihan penyusunan laporan keuangan untuk Wajib Pajak UMKM berbasis SAK EMKM sebagai dasar pelaporan SPT Tahunan yang telah diselenggarakan ini. Pengetahuan tentang penyusunan pelaporan keuangan dan pajak merupakan pengetahuan yang tidak dapat dipisahkan. Tanpa memiliki pengetahuan akuntansi, Wajib Pajak tidak dapat menyusun laporan keuangan dengan baik sehingga tidak memiliki dasar untuk penyusunan SPT Tahunannya. Tanpa memiliki pengetahuan perpajakan, Wajib Pajak tidak dapat memenuhi kewajiban perpajakannya dengan baik. Gambar 1 menunjukkan proses penyampaian materi tentang penyusunan laporan akuntansi berbasis SAK EMKM.

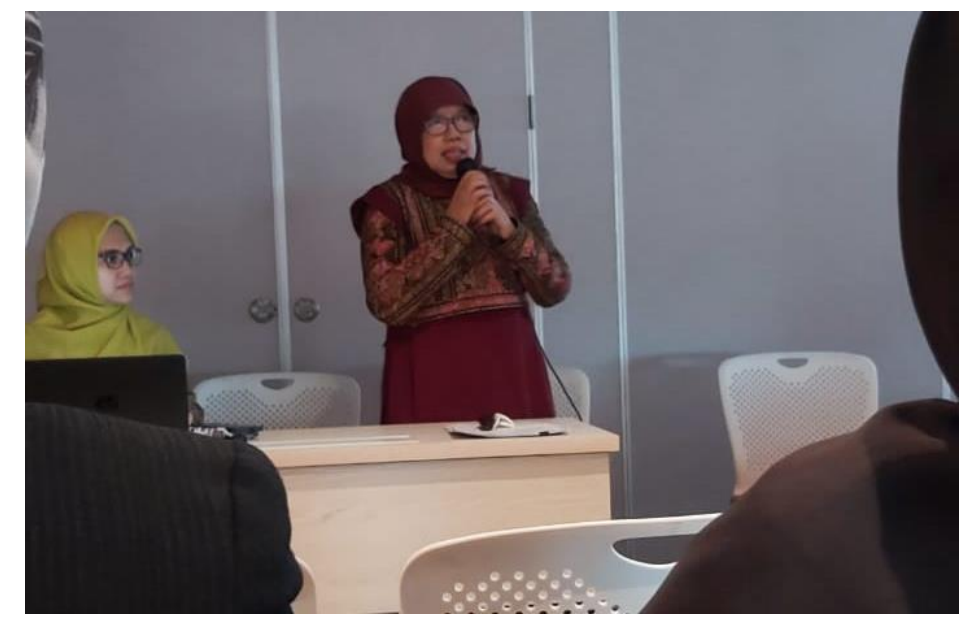

Gambar 1. Pemberian materi tentang penyusunan laporan akuntansi berbasis SAK EMKM

Pengenalan laporan keuangan berbasis SAK EMKM menjadi hal yang sangat diperlukan oleh pelaku UMKM. Para peserta yang hadir umumnya beranggapan bahwa menyusun laporan keuangan adalah sesuatu yang rumit, terlebih lagi untuk peserta yang tidak memiliki latar belakang akuntansi atau untuk peserta yang usahanya baru berdiri. Dengan demikian, pelatihan penyusunan laporan keuangan berbasis SAK EMKM menjadi "angin segar" bagi para peserta untuk mengatasi permasalahan yang dihadapi selama ini. Pembahasan materi dimulai dari konsep dan prinsip dasar penyusunan laporan keuangan berbasis SAK EMKM; komponen laporan keuangan; pengakuan dan teknik pengukuran untuk akun-akun yang umumnya digunakan; hingga contoh laporan keuangannya. Berbeda dari standar akuntansi yang berlaku umum, SAK EMKM hanya memperkenankan tiga komponen laporan keuangan saja, di antaranya: 1) Laporan Posisi Keuangan; 2) Laporan Laba Rugi; dan 3) Catatan atas Laporan Keuangan. Gambar 2, 3, dan 4 merupakan contoh laporan keuangan berbasis SAK EMKM. 
JURNAL ABDIMAS BSI

Jurnal Pengabdian Kepada Masyarakat

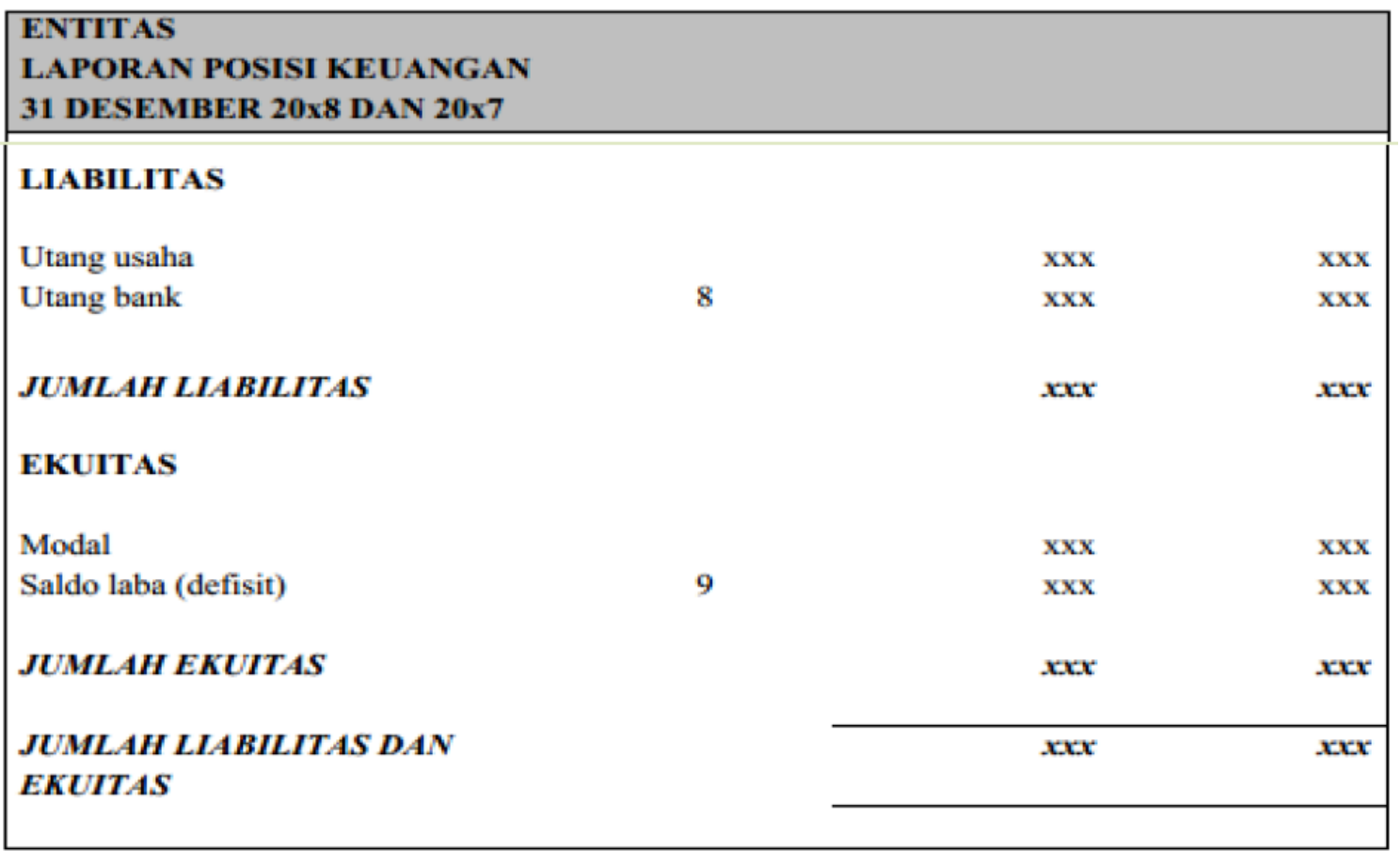

Gambar 2. Contoh Laporan Posisi Keuangan

\begin{tabular}{|c|c|c|c|}
\hline \multicolumn{4}{|c|}{$\begin{array}{l}\text { ENTITAS } \\
\text { LAPORAN LABA RUGI } \\
\text { UNTUK TAHUN-TAHUN YANG BERAKHIR } 31 \text { DESEMBER 20X8 DAN 20x7 }\end{array}$} \\
\hline PENDAPATAN & Catatan & $20 \times 8$ & $\underline{20 \times 7}$ \\
\hline Pendapatan usaha & 10 & $\mathbf{x x x}$ & $\mathbf{x x \mathbf { x }}$ \\
\hline Pendapatan lain-lain & & $\mathbf{x x x}$ & $\mathbf{x x x}$ \\
\hline JUMLAH PENDAPATAN & & $x x x$ & $x x x$ \\
\hline \multicolumn{4}{|l|}{ BEBAN } \\
\hline Beban usaha & & $\mathbf{x x x}$ & $\mathbf{x x \mathbf { x }}$ \\
\hline Beban lain-lain & 11 & $\mathbf{x x x}$ & $\mathbf{x x x}$ \\
\hline JUMLAH BEBAN & & $x x x$ & $x x x$ \\
\hline $\begin{array}{l}\text { LABA (RUGI) SEBELUM PAJAK } \\
\text { PENGHASILAN }\end{array}$ & & $\mathbf{x x x}$ & $\mathbf{x x x}$ \\
\hline Beban pajak penghasilan & 12 & $\mathbf{x x x}$ & $\mathbf{x x x}$ \\
\hline $\begin{array}{l}\text { LABA (RUGI) SETELAH PAJAK } \\
\text { PENGHASILAN }\end{array}$ & & $\mathbf{x x x}$ & $\mathbf{x x x}$ \\
\hline
\end{tabular}

Gambar 3. Contoh Laporan Laba Rugi 


\section{JURNAL ABDIMAS BSI}

Jurnal Pengabdian Kepada Masyarakat

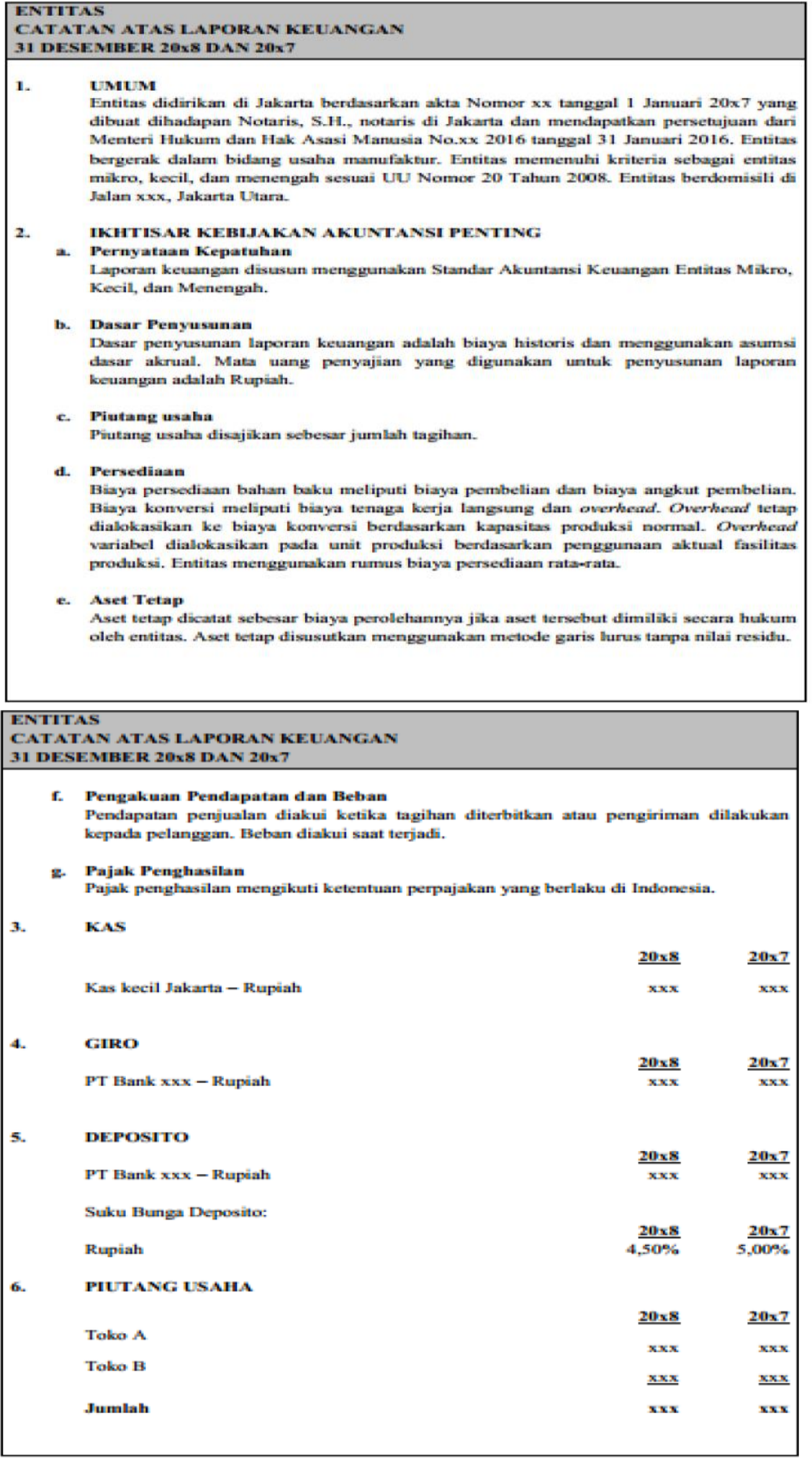




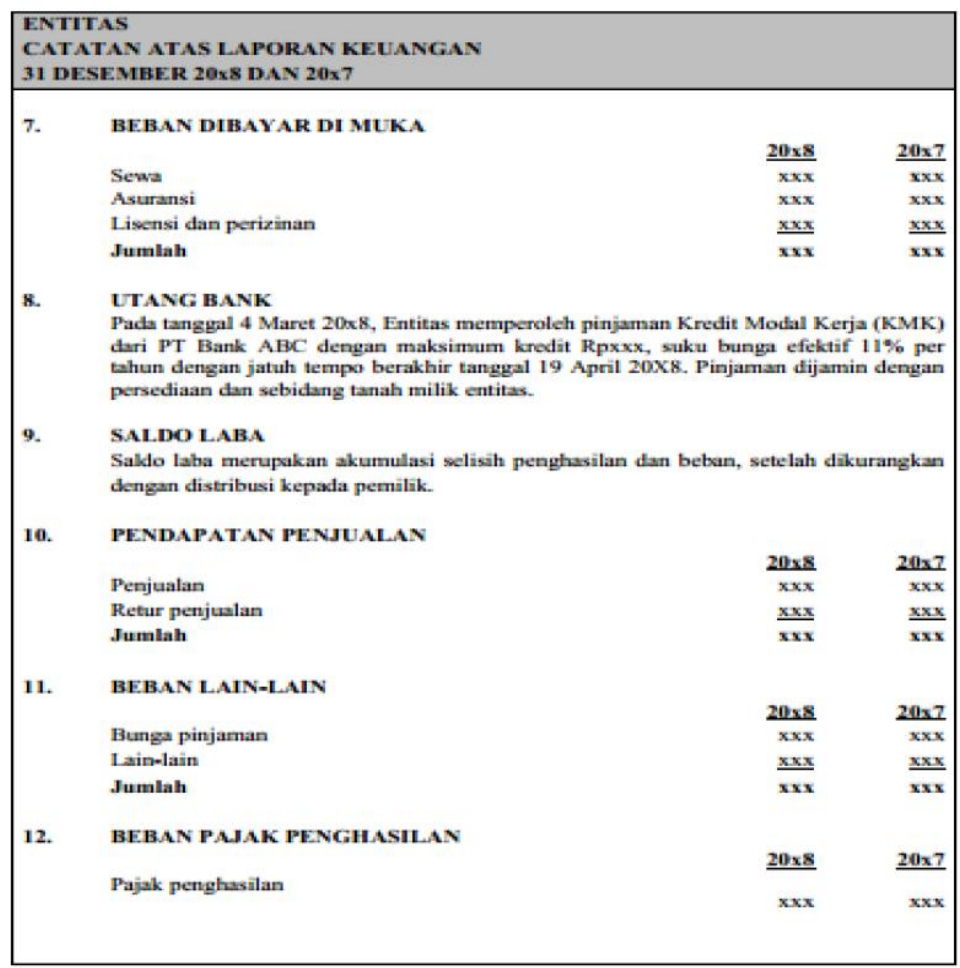

Gambar 4. Contoh Catatan atas Laporan Keuangan

Setelah memahami cara menyusun laporan keuangan, Wajib Pajak UMKM akan lebih mudah dalam memahami mekanisme penghitungan dan pelaporan pajak. Hal ini terjadi karena penyusunan laporan pajak suatu usaha umumnya didasarkan pada laporan keuangan usaha tersebut. Oleh karena seluruh peserta merupakan Wajib Pajak UMKM, materi perpajakan yang dibahas terfokus pada Pajak Penghasilan UMKM yang diatur dalam Peraturan Pemerintah Nomor 23 Tahun 2018. Gambar 5 menunjukkan proses pemberian materi pajak serta diskusi tentang kasus atau masalah perpajakan yang dihadapi oleh para peserta.

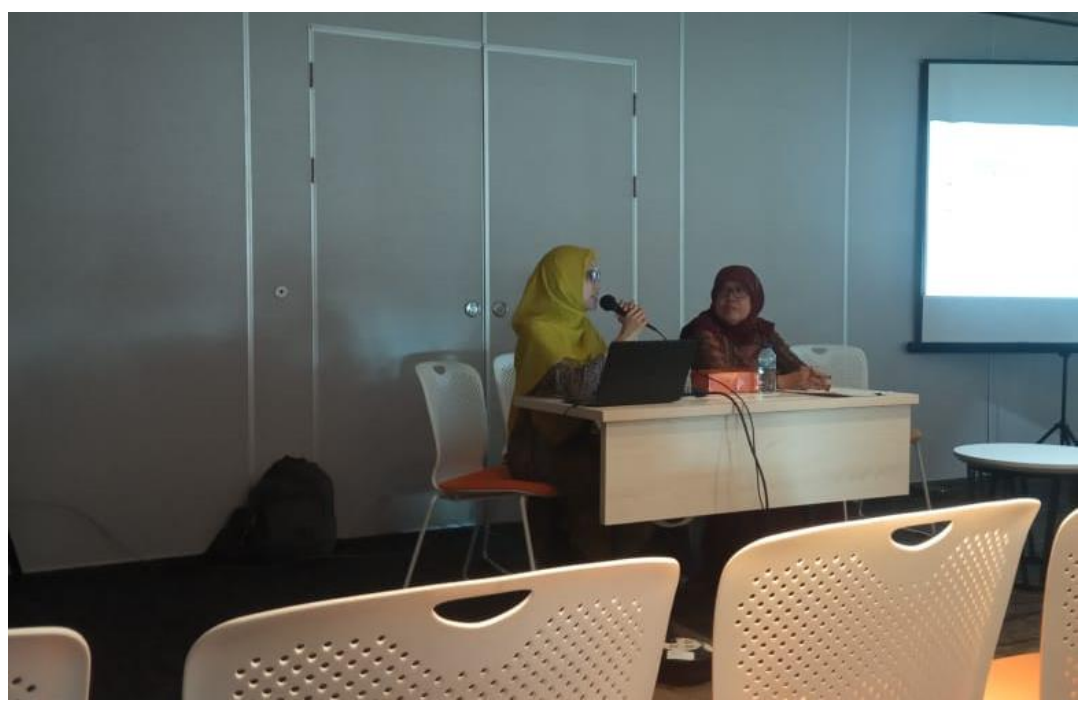

Gambar 5. Pemberian materi tentang penyusunan laporan pajak berdasarkan Peraturan Pemerintah Nomor 23 Tahun 2018 


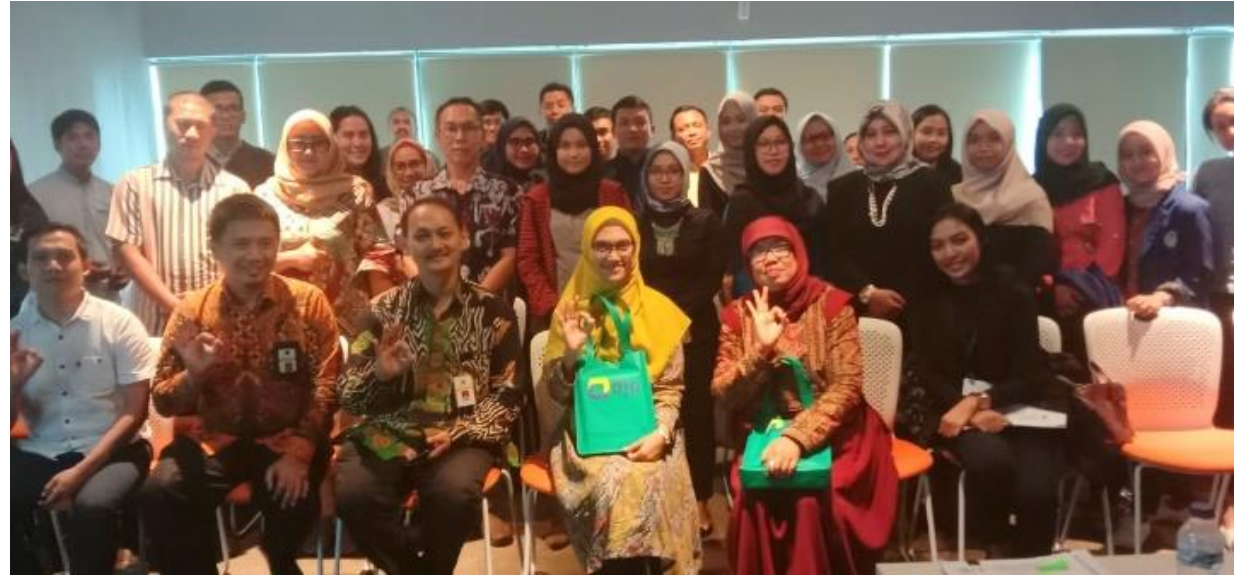

Gambar 6. Penutupan Kegiatan Pengabdian kepada Masyarakat

Dalam proses diskusi, antusiasme peserta sangat tinggi. Begitu banyak pertanyaan yang diajukan oleh peserta. Oleh karena pelatihan sehari ini dirasa kurang, kegiatan pengabdian kepada masyarakat ini dilanjutkan dengan sesi pendampingan. Sesi pendampingan penyusunan laporan keuangan dan pajak diselenggarakan di Universitas Trilogi. Gambar 7 menunjukkan proses pendampingan penyusunan laporan keuangan.

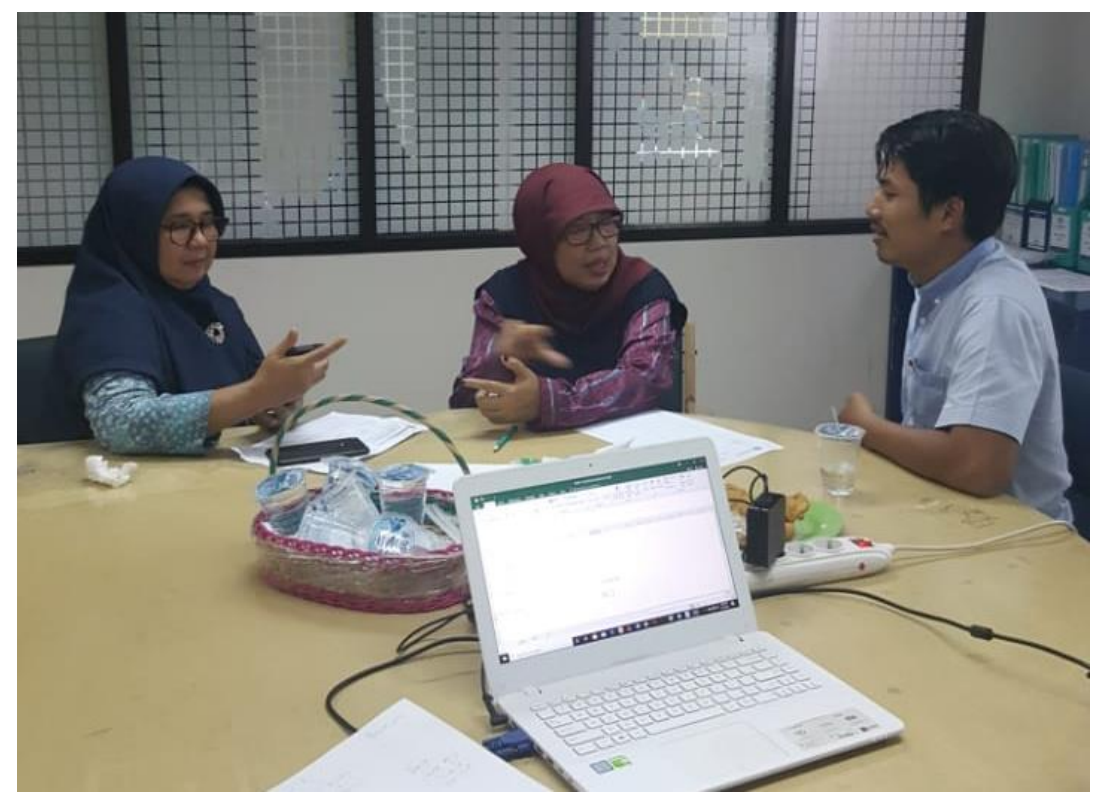

Gambar 7 Proses Pendampingan Penyusunan Laporan Keuangan

Sesi ini sifatnya opsional, hanya diperuntukkan bagi Wajib Pajak UMKM yang memerlukan pendampingan khusus. Peserta yang mengikuti sesi pendampingan umumnya merupakan Wajib Pajak UMKM baru yang tidak memiliki latar belakang akuntansi. Dengan adanya kegiatan pengabdian kepada masyarakat berupa pelatihan dan pendampingan, para peserta diharapkan mendapatkan pemahaman yang lebih baik dalam penyusunan laporan keuangan berbasis SAK EMKM dan dapat melaporkan SPT Tahunannya dengan tepat waktu. 


\section{JURNAL ABDIMAS BSI}

Jurnal Pengabdian Kepada Masyarakat

\section{Simpulan dan Rekomendasi}

Pelatihan penyusunan laporan keuangan untuk Wajib Pajak UMKM berbasis SAK EMKM sebagai dasar pelaporan SPT Tahunan mendapatkan apresiasi yang tinggi dari para peserta. Oleh karena waktu penyelenggaraannya dirasa cukup singkat dan antusiasme peserta sangat tinggi, tim pengabdian memutuskan untuk melakukan sesi pendampingan di luar sesi pelatihan tersebut. Tujuannya, agar para peserta yang memiliki persoalan dalam pelaporan keuangan dan pajak dapat segera teratasi sebelum batas pelaporan SPT Tahunan tiba. Dengan demikian, diharapkan Wajib Pajak UMKM dapat melaporkan SPT Tahunan tepat waktu dan terhindar dari sanksi administrasi perpajakan. Selain itu, dengan adanya kegiatan ini diharapkan dapat turut meningkatkan kesaradan dan kepatuhan Wajib Pajak dalam melaksanakan kewajiban perpajakannya. Selanjutnya, diharapkan kegiatan pengabdian kepada masyarakat semacam ini menjadi kegiatan yang berkelanjutan di masa yang akan datang.

\section{Penghargaan}

Penulis mengucapkan terima kasih kepada pihak-pihak yang telah memberi dukungan terhadap acara pengabdian kepada masyarakat ini. Ucapan terima kasih penulis sampaikan kepada:

1. Perwakilan Kantor Wilayah DJP Jakarta Selatan 1

2. Perwakilan KPP Pratama Pancoran Jakarta Selatan

3. Rektor Universitas Trilogi

4. Dekan Fakultas Ekonomi dan Bisnis Universitas Trilogi

5. Ketua Program Studi S1 Akuntansi Universitas Trilogi.

6. Ketua LPPM Universitas Trilogi

\section{Daftar Pustaka}

Darmayanti, E. F., \& Rahayu, S. R. (2017). Sosialisasi Pajak kepada Para Pedagang untuk Meningkatkan Kesadaran, Kepercayaan, dan Kepatuhan sebagai Wajib Pajak. Sinar Sang Surya, Vol. 1 (1), 91-100.

Firmansyah, A., Arham, A., Nor, A. M. E., \& Simanjuntak, N. F. (2019). Edukasi dan Pendampingan Pelaksanaan Kewajiban Perpajakan Usaha Mikro Kecil dan Menengah pada UMKM XYZ. INTERVENSI KOMUNITAS Jurnal Pengabdian Masyarakat, Vol. 1 (1), 57-64.

Indrawan, B., \& Binekas, B. (2018). Pemahaman Pajak dan Pengetahuan Pajak terhadap Kepatuhan Wajib Pajak UKM. Jurnal Riset Akuntansi dan Keuangan, 6 (3), 419-428.

Kementerian Koperasi dan UKM (2018). Perkembangan Data Usaha Mikro, Kecil, dan Menengah (UMKM) dan Usaha Besar (UB) Tahun 2017-2018. http://www.depkop.go.id/data-umkm 


\section{JURNAL ABDIMAS BSI}

Jurnal Pengabdian Kepada Masyarakat

Maulinda, A., \& Lasmana, M. S. (2015). Faktor-faktor yang Mempengaruhi Tingkat Kepatuhan Pengusaha Kena Pajak Badan Pedagang Pengecer pada Kantor Wilayah Direktorat Jenderal Pajak Jawa Timur I. Jurnal Ekonomi dan Bisnis, Vol. XXV (1), 44-53.

Onasis, D., Listihana, W. D., \& Aquino, A. (2017). Pelatihan Penyusunan dan Penyajian Laporan Keuangan untuk Usaha Mikro, Kecil, dan Menengah yang Berbasis Standar Akuntansi Keuangan (SAK) Entitas Tanpa Akuntabilitas Publik (ETAP) di Desa Muara Jalai Kecamatan Kampar Utara Kabupaten Kampar. Dinamisia - Jurnal Pengabdian Kepada Masyarakat, Vol. 1(1), 15-22.

Peraturan Pemerintah Nomor 23 Tahun 2018 tentang tentang Pajak Penghasilan atas Penghasilan dari Usaha yang Diterima atau Diperoleh Wajib Pajak yang Memiliki Peredaran Bruto Tertentu.

Rachmawati, N. A., \& Ramayanti, R. (2016). Manfaat Pemberian Insentif Pajak Penghasilan dalam Kepatuhan Wajib Pajak UMKM. Jurnal Akuntansi, Ekonomi dan Manajemen Bisnis, Vol. 4 (2), 176-185.

Raflis, R., Wijaya, R. S., Nini, \& Rahmi, Y. Y. (2019). Pelatihan Penerapan Akuntansi dan Pajak Pada Badan Usaha Milik Nagari Barokah Lamo Kabupaten Sijunjung. DINAMISIA - Jurnal Pengabdian Kepada Masyarakat, Vol. 3, Special Issue Juni 2019, 85-89. 